\title{
The Relationship of Interpersonal Communication, Working Motivation and Transformational Leadership to Teachers' Job Satisfaction
}

\author{
Setia Wahyuni ${ }^{1}$, Suparno Eko Widodo ${ }^{2}$, Rita Retnowati ${ }^{3}$ \\ Post Graduate Program, Universitas Pakuan Bogor, Indonesia
}

\begin{abstract}
The aim of this study is to examine the influence of interpersonal communication, working motivation and transformational leadership to teachers' job satisfaction either individually or jointly. Variables of interpersonal communication, working motivation and transformational leadership serve as independent variables while the dependent variable is teacher's job satisfaction. The study was conducted on proportional randomly selected 116 non-permanent teachers of private vocational high school in the city of Jambi, Indonesia. Using mix method, sequential explanatory design is applied where quantitative come first. The study both quantitatively and qualitatively reveals that there is a positive significant relationship among variables under the following distribution of coefficient of correlation: interpersonal communication to teacher's job satisfaction $=0.942$, working motivation to teacher's job satisfaction $=0.768$, transformational leadership to teacher's job satisfaction $=0.567$ and when tested together it produces coefficient of correlation $=0.800$ indicating the existence of other $20 \%$ variables not including in the model affecting job satisfaction within the private vocational highs school teachers' working environments.
\end{abstract}

Keywords: Interpersonal Communication, Working Motivation, Transformational Leadership, Job Satisfaction

\section{INTRODUCTION}

Education is an essential element of a person's life as well as a strategic aspect for a country which is complex, dynamic and contextual. One of the very important influences in the world of education in Indonesia is the presence of teachers as educators and teachers who will direct the generation of the nation to the right direction and making teachers are one of the most important parts of the learning process. To perform well, the teacher must be satisfied first before delivering the lessons to students.

Results of initial survey on job satisfaction in private vocational school teachers in Jambi, Indonesia, showed that the respondents (teachers) do not get a feeling of job satisfaction. Since job satisfaction is considered as a a significant contributing factor to the teacher's performance, this problem must be taken seriously. Some factors may contribute to dissatisfaction within Indonesian setting like inadequate compensation or facilities provided by the government, lack of appreciation of the achievements of teachers, lack of facilities to carry out the work, less support to professional development according to their interests and talents, non-intensive compensation to support the welfare of teachers, less teacher involvement in school development, lack of support to improve educational qualifications and competence, as well as lack of harmony in the workplace. Given the important role of teachers in improving the quality of education, it is expected their concern are listened to and paid attention by various parties in order the teachers can carry out the task with enthusiasm, responsibility and sincerity to educate the next qualified and noble generation. Based on the background and the results of the identification of the problem, the formulation of the problem is :

Does interpersonal communication positively affect private vocational school teacher's job satisfaction?

Does working motivation positively affect private vocational school teacher's job satisfaction?

Does transformational leadership positively affect private vocational school teacher's job satisfaction?

Do interpersonal communication, working motivation and transformational leadership altogether positively affect private vocational school teacher's job satisfaction? 


\section{LITERATURE REVIEW}

Gibson, et.al (2012)) argues interpersonal communication is the main way in daily managerial communication as usually more than a quarter of managerial communication occurs face to face with the following indicators: a) transparency, b) honesty, c) feedback. Schermerhorn (2004) stated that it would be useful to look at human communication as a process to send and receive symbols containing a message from one person to another. The basic process between people is the basis for the discussion of issues of greater communication within an organization and there are three factors in interpersonal communication to foster good interpersonal relationships: a) believe (trust), b) supportive attitude (supportiveness), c) an open attitude (open-mindedness).

McShane and Glinov (2012) concluded that effective interpersonal communication depends on the ability of the sender to get messages from others and receiver performance as an active listener. The indicators are: a) empathy, a person's ability to understand, sensitive to the feelings, thoughts, and situations of others, b) repeating the message: repeating key points several times, c) using time effectively: the message that compete with another message, d) noise, so that the recipient is not disturbed by anything else, and descriptive, focusing on the problem, not the person. Based on the above description, it can be synthesized that interpersonal communications are the delivery and reception of messages in the exchange of information between individuals, directly as well as generating feedback so that the message can be understood by the two parties. The indicators are a) the transmission of information, b) sensitive to the feelings of others, c) feedback, d) information acceptance e) using time effectively, f) comfortable conditions when obtaining information.

The concept of motivation is derived from a Latin word "movere" which means "to move". Motivation is what moves the employees from dullness to interest. It is just like the steering of the vehicles that directs and shapes employees' activities. Motivation has been defined as the "Drive or energy that compels people to act with energy and persistence towards some goal" (Berman, Bowman, West, \& Wart, 2010). "Motivation is a goal-directed behavior which involves taking a course of action which leads to the attainment of a goal or a specific valued reward" (Armstrong, 2006).

The level of employee motivation, commitment and job atisfaction could be gauged by the volume of employees' turn over during a certain period of time. Employees with high job satisfaction are more focused towards their jobs (Hackett, Lapierre, \& Hausdorf, 2001), likely to have less turnover and leaving intensions and are more motivated to stay with the organization. They grow in expertise and thus become even more valuable to their employer and the organization. Importance of motivation and job satisfaction in the workplace is obvious as well motivated and committed employees with high levels of job satisfaction affect both their own as well as organizational outcomes (Rajiani, 2010). Employees with high levels of job satisfaction go on work in time and are usually more motivated to put extra efforts, on the other hand, employees having minor level of job satisfaction are least motivated and have more excuses such as illness or transportation problems etc. as compared to highly satisfied employees.

Bernard M. Bass and Ronald E. Riggio (2006) defines transformational leadership as behavior which can stimulate and inspire followers to achieve results in the process of developing leadership skills, vision and goals given organization, to challenge itself to innovate, solve problems, and develop the ability of the leadership to subordinates through guiding, mentoring, ,challenging and supporting. "Transformational leaders, on the other hand, are then those who stimulate and inspire followers both in achieving extraordinary outcomes and developing their own leadership capacity".

Gary Yukl (2006) stated that transformational leadership is the behavior of a leader who is able to call on his followers moral values in their efforts to raise awareness of ethical issues and mobilize energy and resources to reform institutions. Factors associated with the above definition are: 1) communicating the vision, 2) expressive, 3) a risk taker and sacrificed himself, 4) communicating high expectations, 5) consistent behavior vision, 6) managing the respect of subordinates against leadership, 7) establishing the existence of a group or organization, 8) empowering subordinates.

Based on the theories mentioned above, it can be synthesized that transformational leadership is the behavior of a leader who can inspire subordinates (teachers) to commit to the vision of the school, communicating, motivating, directing, empowering subordinates, to be a model, developing the potential of subordinates as well as a new perspective in solving the problem. The dimensions and indicators are: 1) the influence of the ideal toward subordinates, 2) the inspiration that motivates, 3) 
intellectual stimulation, 4) treatment of subordinates, 5) communication skills, 6) the giver of challenge and support.

Rue and Byars (2000) defines job satisfaction as an employee's general attitude towards work. This can be affected by factors such as working conditions, pay and benefits, employee attitudes towards the organisation, supervision of the work, the age and health. That mindset can be negative or positive depending on the mindset of the employees toward the main components of job satisfaction. Rue and Byars give us the understanding that job satisfaction does not come naturally for granted; but many factors that cause an employee be satisfied. Robins and Judge (2012) defines that job satisfaction is evaluative statement either for pleasure or unpleasure toward individual objects or events. Discontent is essentially a person's assessment of the work. Many factors affect employee satisfaction, including: salaries, allowances, achievement, autonomy, recognition, communication, working conditions, the importance of work, coworkers, professionalism, organisational climate, interpersonal relationships, working for a prominent institutions, supervisory support, positive activity, job security, workplace flexibility, working in a cohesive team and genetic factors. Low work satisfaction is associated with the laborious tasks such as documentation, repetition task, the tension in the role expectations, ambitious role, conflicted role, feeling overloaded, increasing the need to be available for overtime, a co-worker relationships, personal factors and organisational factors.

Based on theory explored, it can be concluded that job satisfaction is an attitude or feelings towards a job that makes him feel satisfied or not. Some indicators that are related to job satisfaction of school teachers are (a) the receipt of salary (b) promotion opportunities (c) organisational environment, (d) allowances.

\section{Data Collection}

This study applies mix method with direct observation to the field aimed at analyzing the phenomenon occur when the research took place then confirm the finding by using direct depth interview. This way, writers apply Sequential Explanatory Mixed Methods. Descriptive statistics and quantitative analysis are used for finding initial solution to the problem encountered. The sample of this study were 116 private vocational high school teachers located in 9 (nine) schools in Jambi, Indonesia.

Techniques of data collection in this study is in the form of questionnaire. The normality assumption is prerequisites to proceed to further test. Analysis is conducted with multiple linear regression and hypothesis testing is performed at a significance level of 0.05 .

Depth interview with vice headmaster was perform to confirm the result of quantitative findings. The implication of the research findings is then discussed.

\section{RESULT AND DISCUSSION}

The teachers of selected schools were asked to participate in the survey by stating their opinions for four different measures on interpersonal communication, working motivation, transformational leadership and job satisfaction. The normality is performed with Lilliefors test. Data are normally distributed as the value of each variable is not exceeding the critical value for Lilliefors test. The Lilliefors normality test values for interpersonal communication, working motivation, transformational leadership to job satisfaction are $0.064,0.662$ and 0.092 respectively below the critical value of 0.093 for $n=116$.

\subsection{The Effect of Interpersonal Communication to Job Satisfaction}

Hypothesis testing confirms that interpersonal communication positively affects job satisfaction with correlation coefficient value of 0.970 and the coefficient of determination $=0.940$. This means that only $94 \%$ of job satisfaction is determined by interpersonal communication, while the other $6 \%$ is contributed by other variables. Similarly, result of qualitative research interviews, observation and documentation in three private Junior High School in the city of Jambi , confirms the tendency of the relationship between interpersonal communication with job satisfaction. This finding strengthens the quantitative research hypothesis results testing that there is a positive significant relationship between interpersonal communication and job satisfaction.

This finding is in line with the study of Dehaghani, Habibollah Hosseini, Khosrow Tavakol, Soheila Bakhtiyari in University of Isfahan (2006), proving that there is a significant relationship between interpersonal communication and job satisfaction. 
Based on the description above can be concluded that the higher interpersonal communication, the higher the results of teacher job satisfaction. Thus the findings of facts and data in this analysis further supports previous findings about the relationship between interpersonal communication and job satisfaction of teachers.

\subsection{Working Motivation to Job Satisfaction}

Hypothesis testing confirms that working motivation positively affects job satisfaction with the coefficient of determination $=0.767$. This means that only $76.7 \%$ of job satisfaction is determined by working motivation variable, while the other $23.3 \%$ is contributed by other variables. Similarly, result of qualitative research interviews, observation and documentation in three private vocational school in the city of Jambi , confirms the tendency of the relationship between working motivation to job satisfaction. This finding strengthens the quantitative research hypothesis results testing that there is a positive significant relationship between working motivation and job satisfaction.

Previous study has proved that motivation has a positive influence to job satisfaction (Danish and Ali, 2010). So the higher working motivation, the higher the job satisfaction making the findings of facts and data in this analysis further supports previous findings about the positive influence of work motivation to job satisfaction within teachers' working environment.

\subsection{The Effect of Transformational Leadership to Job Satisfaction}

Hypothesis testing confirms that transformational leadership positively affects job satisfaction with the coefficient of determination $=0.753$. This means that $75.3 \%$ of job satisfaction is determined by transformational leadership variable, while the other $24.7 \%$ is contributed by other variables. Similarly, result of qualitative research interviews, observation and documentation in three private Junior High Schools in the city of Jambi confirms the tendency of the relationship between transformational leadership and job satisfaction. This finding strengthens the quantitative research hypothesis results testing that there is a positive significant relationship between transformational leadership and job satisfaction. The results of relevant previously research has also shown that transformational leadership has a positive influence with job satisfaction (Mohammad, Hussein Ali Al-Zeaud, Ayat Mohammad Essam Batayneh, 2011) making facts and data in this analysis further supports previous findings on the positive influence of transformational leadership and job satisfaction of teachers.

\subsection{Interaction of Interpersonal Communication, Working Motivation and Transformational Leadership to Job Satisfaction}

When tested together, hypothesis testing results show that there is a significant relationship between interpersonal communication, working motivation and transformational leadership to job satisfaction. The regression equation generated is $\hat{Y}=197.39+0.348 \mathrm{X}_{1}+0.170 \mathrm{X}_{2}+0.615 \mathrm{X}_{3}$ with correlation of coefficient values $=0.895$ and the coefficient of determination $=0.800$. This means that $80 \%$ of job satisfaction is caused by variables of interpersonal communication, working motivation and transformational leadership while $20 \%$ is contributed by other variables not included in the model. Result of qualitative research interviews, observation and documentation in three private vocational schools in the city of Jambi confirms the relationship among interpersonal communication, working motivation and transformational leadership to job satisfaction. This finding strengthens the quantitative research hypothesis results testing that there is a positive significant relationship among those mentioned variables. Qualitative research also reveals that other factors affecting job satisfaction in the respective school are school promotion, cost of education, management of the foundation and human power allocation.

\section{Conclusion}

The findings reveal that there is a positive and significant direct effect between the interpersonal communication, working motivation and transformational leadership to job satisfaction.

Based on the initial design of the constellation between variables, the results showed that the contribution of interpersonal communication to job satisfaction is $94 \%$, working motivation is $76.7 \%$, and transformational leadership is $75.3 \%$ indicating the highest individual contribution to the teachers' job satisfaction is work interpersonal communication. When combined together, contribution of the three variables reaches $80 \%$ indicating the contribution of other variables not included in the model to predict job satisfaction are $20 \%$ confirming this model is of good-fit. Other researchers 
wishing to conduct similar studies may include other variables such as; teacher professionalism, achievement motivation, work culture of teachers, teachers' resilience, creativity, work experience, training, principal's management, decision-making techniques and so forth. This confirms Rajiani (2010) comprehension that it is necessary to conduct a comprehensive and critical analysis to identify the factors that enhance and promote job satisfaction leading to organizational commitment. Factors related to personal characteristics, organizational environment, and leadership behaviors may be found to predict job satisfaction mainly among non-permanent teachers in private vocational high schools which are rarely explored.

\section{REFERENCES}

Armstrong, M. "Motivation." A Handbook of Human Resource Management Practice, 2006, pp. 253254. London: Kogan Page Limited.

Berman, E. M., Bowman, J. S., West, J. P., \& Wart, M. R. V. "Motivation: Possible, Probable or Impossible? “ Human Resource Management in Public Service: Paradoxes, Processes and Problems, 2010, pp. 180. California: SAGE Publications, Inc.

Bernard M., Bass dan Ronald E. Riggio (2006). Transformational Leadership-2 ${ }^{\text {nd }}$ ed. New Jersey: Lawrence Erlbaum Associates.

Danish, R. Q., \& Usman, A. (2010). Impact of reward and recognition on job satisfaction and motivation: An empirical study from Pakistan. International journal of business and management, 5(2), 159.

Dehaghani, A. R., Hosseini, H., Tavakol, K., \& Bakhtiyari, S. (2010). Relationship between communication manners of head nurses with job satisfaction of nurses under their supervision in educational hospitals of Isfahan University of Medical Sciences in 2006. Iran J Nurs Midwifery Res, 15(2), 49-53.

Hackett, R. D., Lapierre, L. M., \& Hausdorf, P. A. "Understanding the links between work commitment constructs. “ Journal of Vocational Behavior, 58, 2001, pp. 392-413.

Gibson, J.L., John M. Ivancevich, James H. Donelly Jr, \& Robert Konopaske. Organizational: Behavior, Structure, Processes, 2012, New York: Mc Graw-Hill. pp. 344-345.

McShane/Von Glinow, Organizational Behavior, Emerging Knowledge and Practice for the Real World, 2010, pp. 202. New York: McGraw-Hill Irwin.

Mohammad, S. I. S., Al-Zeaud, H. A., \& Batayneh, A. M. E. B. (2011). The relationship between transformational leadership and employees' satisfaction at Jordanian private hospitals. Business and Economic Horizons, 5(2), 35-46.

Rajiani, I. "Applying Personality Traits to Predict Loyalty and Neglect among Employees of Bank Jatim Located in 10 Big Cities of East Java (Mc Crae's and Hofstede's Theories on effect of Culture to Personality Revisited)." Jurnal Aplikasi Manajemen 8, no. 3, 2010, pp-617-623.

Rue, Leslie W. and Lioyd L Byars (2007). "Supervision Key Link to Productivity”. New York: Mc Graw Hill, pp.123.

Robbins, S. P. \& T. A. Judge (2012). Organizational Behavior. New Jersey: Pearson Education.

Schemerhorn, J.R., James G. Hunt, Richard N. Osborn \& Mary Uhl-Bien, "Organizational Behavior" 2007, pp. 111,John Wiley \& Sons Inc.

Yukl, Gary (2010). Leadership in Organizations $-7^{\text {th }}$ ed. New Jersey: Pearson Education, Inc, Upper Saddle River. 